\title{
Hyperlactataemia during intravenous feeding in childhood
}

\author{
A. AYNSLEY-GREEN, J. D. BAUM, K. G. M. M. ALBERTI,* and H. F. WOODS \\ From the Department of Paediatrics and the Nuffield Department of Clinical Medicine, University of Oxford, \\ and the M.R.C. Clinical Pharmacology Unit, Radcliffe Infirmary, Oxford
}

\begin{abstract}
Aynsley-Green, A., Baum, J. D., Alberti, K. G. M. M., and Woods, H. F. (1974). Archives of Disease in Childhood, 49, 647. Hyperlactataemia during intravenous feeding in childhood. A recently introduced synthetic amino acid preparation, Aminoplex 5, appeared suitable for use in intravenous feeding in childhood because it has a low sodium concentration and high caloric value, achieved by using sorbitol and ethanol. The effects of a 2-hour infusion of Aminoplex 5 at $5 \mathrm{ml}$ or $10 \mathrm{ml} / \mathrm{kg}$ per hr on the concentrations of several blood metabolites and hormones were investigated in 8 children. All the children showed a rise in blood lactate concentration (range of increase 0.23 to $6.72 \mathrm{mmol} / \mathrm{l}$ ) and lactate/pyruvate ratio (range of increase 2.5 to 18.0 ) and a small consistent fall in blood acetoacetate concentration. The effects were dose related. Free blood fructose was shown in 7 children after Aminoplex 5, the only exception being a preterm infant. No significant changes were found in plasma insulin or growth hormone concentrations. We suggest that the use of this preparation should be accompanied by frequent estimations of blood lactate or acid-base status.
\end{abstract}

The use of parenteral nutrition in the management of seriously ill children has increased. Such therapy is not without danger, and there have been reports indicating some of the metabolic abnormalities which can arise (Harries, 1971; Heird et al., 1972). The situation is complicated by the multiplicity of recommended regimens and by the availability of several amino acid preparations which differ in amino acid content, sodium concentration, carbohydrate source, and caloric value. Furthermore, preparations used in adult patients may be unsuitable for use in childhood.

We have therefore investigated the effects of an infusion of a recently introduced synthetic amino acid preparation (Aminoplex 5 $\dagger$ ) on blood metabolite and hormone concentrations at the start of elective periods of intravenous feeding. This preparation appeared suitable for use in childhood, particularly since it has a low sodium content (35 $\mathrm{mEq} / \mathrm{l}$.) and a high caloric value (1000 cal/1.).

\footnotetext{
Received 4 February 1974.

*Present address: The General Hospital, Tremona Road, Southampton.

†Geistlich Sons Ltd., Chester, England.
}

\section{Patients and methods}

Details of the children and the indications for intravenous feeding are shown in Table $I$. The youngest patient was a preterm infant born at 29 weeks' gestation, who was 3 weeks old at the time of study. The eldest was an 11-year-old boy. The study was performed during the first 6 hours of intravenous feeding, none of the subjects having previously received Aminoplex 5 . The composition of Aminoplex 5 is shown in Table II, and the infusion protocol in Fig. 1. The study was divided into three consecutive 2 -hour periods. Amino-

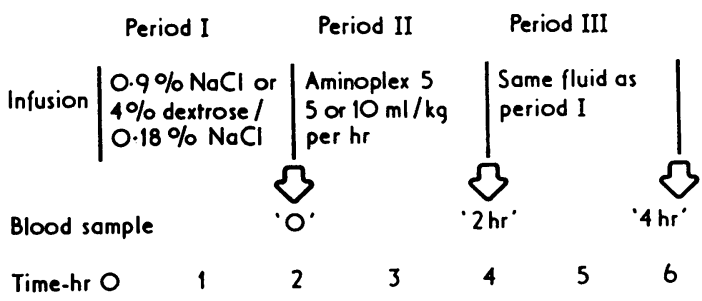

Fig. 1.-Infusion protocol. Aminoplex 5 was infused during the second 2-hour period at 5 or $10 \mathrm{ml} / \mathrm{kg}$ per $\mathrm{hr}$. Saline or dextrose saline was infused at the same rate during the first and last period. Blood samples were drawn at the end of each infusion period. 
TABLE I

Details of patients

\begin{tabular}{|c|c|c|c|c|}
\hline Case no. & Age & Diagnosis & $\begin{array}{l}\text { Aminoplex infusion } \\
\text { rate } \\
(\mathrm{ml} / \mathrm{kg} \text { per } \mathrm{hr})\end{array}$ & $\begin{array}{l}\text { Concurrent drug } \\
\text { administration }\end{array}$ \\
\hline 1 & 3 wk; 29 wk gestation & Necrotizing enterocolitis & 5 & $\begin{array}{l}\text { Cloxacillin, gentamicin, } \\
\text { carbenicillin }\end{array}$ \\
\hline $\begin{array}{l}2 \\
3 \\
4\end{array}$ & $\begin{array}{c}3 \mathrm{mth} \\
18 \mathrm{mth} \\
5 \mathrm{yr}\end{array}$ & $\begin{array}{l}\text { Ulcerative colitis } \\
\text { Viral pneumonia } \\
\text { Cerebral abscess; meningitis; } \\
\text { Fallot's tetralogy }\end{array}$ & $\begin{array}{l}5 \\
5 \\
5\end{array}$ & $\begin{array}{l}\text { Ampicillin, colistin } \\
\text { Ampicillin, cloxacillin } \\
\text { Penicillin, lincomycin, } \\
\text { phenytoin }\end{array}$ \\
\hline $\begin{array}{l}5 \\
6 \\
7 \\
8\end{array}$ & $\begin{array}{c}11 \mathrm{yr} \\
3 \mathrm{dy} ; 40 \mathrm{wk} \text { gestation } \\
3 \mathrm{mth} \\
8 \mathrm{mth}\end{array}$ & $\begin{array}{l}\text { Traumatic paraplegia } \\
\text { Gastroschisis } \\
\text { Malabsorption } \\
\text { Meningitis, hydrocephalus }\end{array}$ & $\begin{array}{r}5 \\
10 \\
10 \\
10\end{array}$ & $\begin{array}{l}\text { Nil } \\
\text { Ampicillin, cloxacillin } \\
\text { Nil } \\
\text { Ampicillin, cloxacillin, } \\
\text { phenobarbitone, phenytoin, } \\
\text { dexamethasone }\end{array}$ \\
\hline
\end{tabular}

TABLE II

Composition of Aminoplex 5 *

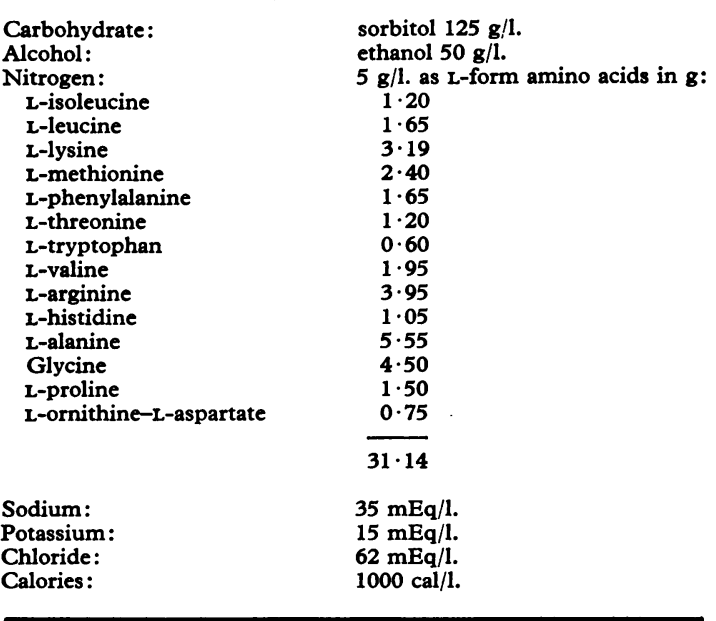

^Information from Data Card, Geistlich L.td., Chester, England.

plex 5 was infused during the second period at $5 \mathrm{ml}$ or 10 $\mathrm{ml} / \mathrm{kg}$ per hr. Sodium chloride $(0.9 \%)$ or $4.3 \%$ dextrose $/ 0 \cdot 18 \%$ sodium chloride was infused at the same rate as Aminoplex 5 during the first and last 2-hour period using the same solution in each child. All solutions were administered via a peripheral vein. Blood samples $(0.5 \mathrm{ml})$ were taken at the end of each infusion period (' 0 ', '2-hour', and '4-hour' samples, respectively). The blood was taken from a radial artery catheter in the premature infant, from capillary blood after heel prick in infants, and by peripheral venepuncture without veneconstriction in the older children. Whole blood $(0.2 \mathrm{ml})$ was immediately added to $2 \mathrm{ml} 5 \%$ perchloric acid for subsequent assay of metabolites. Plasma was used for hormone assay. Blood lactate, pyruvate, acetoacetate, and glucose, and plasma insulin and growth hormone concentrations were measured as described previously (Alberti et al., 1972b). Blood fructose concentrations were measured by an enzymatic method (Slein, 1963).

\section{Results}

Clinical observations. None of the children developed changes in pulse rate, respiratory rate, or clinical condition during the study.

Blood lactate and pyruvate concentrations. Blood lactate concentrations before Aminoplex 5 infusion ranged from 0.52 to $2 \cdot 24 \mathrm{mmol} / \mathrm{l}$. (Fig. 2, Table III). At the end of the Aminoplex 5 infusion an increase in blood lactate concentration was found in all subjects, a greater rise occurring in the 3 children given the high rate of infusion. After the infusion rate of $5 \mathrm{ml} / \mathrm{kg}$ per $\mathrm{hr}$, the mean blood lactate concentration rose significantly from $1 \cdot 12 \pm 0 \cdot 21 \mathrm{mmol} / 1$. to $1 \cdot 92 \pm 0.40 \mathrm{mmol} / \mathrm{l}$., and from $1 \cdot 84 \pm 0 \cdot 18 \mathrm{mmol} / \mathrm{l}$. to $5 \cdot 85 \pm 1 \cdot 10 \mathrm{mmol} / 1$. with twice the rate of infusion. The greatest rise (from $1.49 \mathrm{mmol} / 1$. to $8 \cdot 21 \mathrm{mmol} / 1$.) occurred in one child in the latter group (Case 8).

Blood lactate concentration failed to return to the pre-Aminoplex value in 6 of the 8 children during the final infusion period of $0.9 \%$ saline or dextrose/saline. There were no significant changes in blood pyruvate concentrations. The lactate/ pyruvate $(\mathrm{L} / \mathrm{P})$ ratio was increased at the end of the Aminoplex 5 infusion in all subjects, the increase being dose related (Fig. 2, Table III).

One child (Case 4) who had Fallot's tetralogy with central cyanosis, had an initial $\mathrm{L} / \mathrm{P}$ ratio of 37 despite a minimally raised blood lactate concentration of $1 \cdot 8$ $\mathrm{mmol} / \mathrm{l}$., and this increased to 40 and 43 during the next 4 hours. 

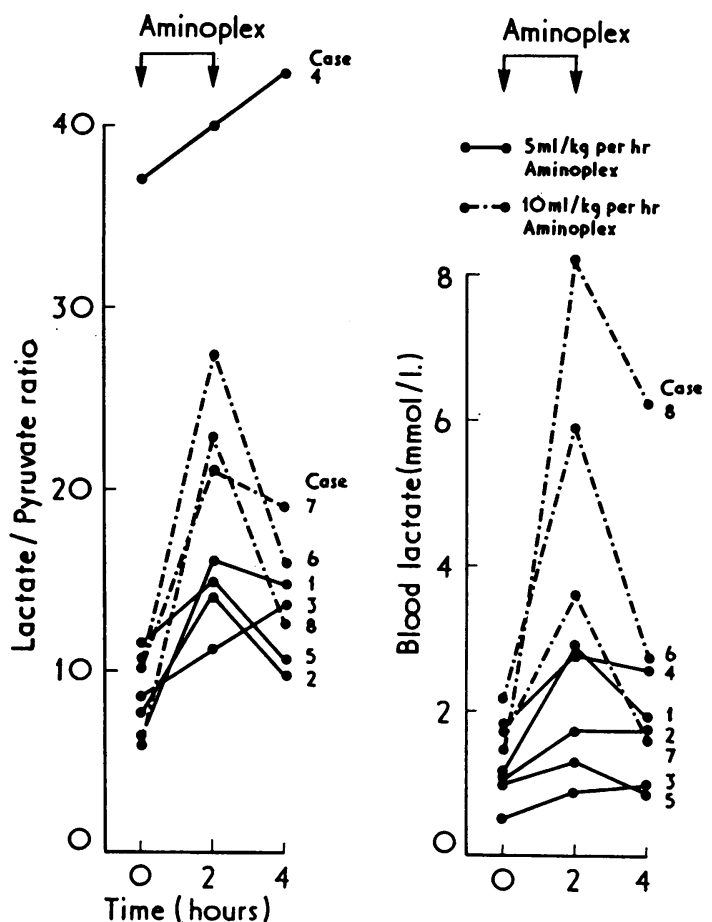

FIG. 2.-Effects of Aminoplex 5 infusion on blood lactate concentration and lactate/pyruvate ratio. Each line represents the values obtained for each child. The time 0 sample was drawn at the end of the first infusion period. The 2-hour sample was taken after Aminoplex 5 infusion, and the 4-hour samples after a final saline or dextrose/saline infusion.

Blood glucose concentrations. Blood glucose concentrations ranged from 1.52 to $9.24 \mathrm{mmol} / \mathrm{l}$. initially (Fig. 3, Table III). An increase in blood glucose concentration occurred after Aminoplex 5 in all 3 children given the high infusion rate. In the preterm infant the initial blood glucose value was low $(1.52 \mathrm{mmol} / 1$., or $27 \mathrm{mg} / 100 \mathrm{ml})$ and though an increase to $2 \cdot 71 \mathrm{mmol} / 1$. (49 mg/100 ml) occurred after Aminoplex 5, the increase was not sustained and fell to $1 \cdot 71 \mathrm{mmol} / 1$. (31 mg/100 ml) 2 hours later.

Blood fructose concentrations. Demonstrable levels of fructose were not found in any of the time 0 samples (Fig. 3, Table III). After the Aminoplex 5 infusion, blood fructose concentrations ranging from 0.26 to $1.54 \mathrm{mmol} / \mathrm{l}$. were found in the children given the high dose. 3 of the 5 children given the low dose were found to have demonstrable blood fructose concentrations after
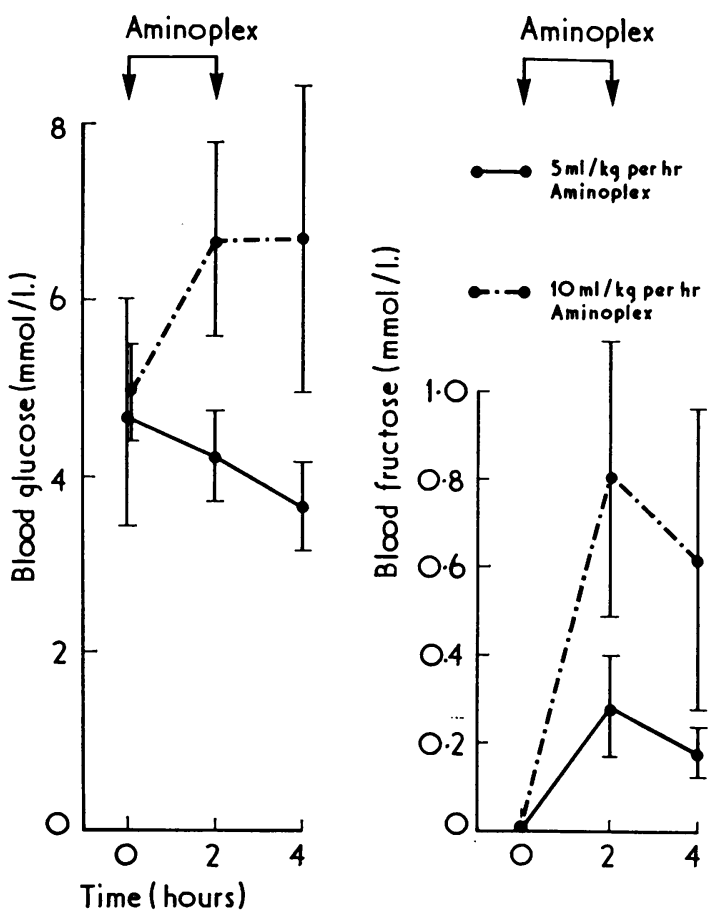

Fig. 3.-Effects of Aminoplex 5 infusion on blood glucose and fructose concentrations. Mean values $\pm S E M$ for groups receiving Aminoplex 5 at $5 \mathrm{ml} / \mathrm{kg}$ per $\mathrm{hr}($ no. $=5$ ) or $10 \mathrm{ml}($ no. $=3$ ) are shown. $A$ rise in blood fructose concentration occurred after Aminoplex 5 infusion for 2 hours in both groups. A rise in blood glucose concentration occurred only in the high dose group.

Aminoplex 5 (range 0.25 to $0.55 \mathrm{mmol} / \mathrm{l}$.) and 4 of the 5 children had demonstrable levels of fructose 2 hours later (range 0.10 to $0.35 \mathrm{mmol} / 1$.). The only infant in whom fructose was not shown at any time was the preterm infant (Case 1).

Blood acetoacetate concentrations. A decrease in acetoacetate concentrations occurred after Aminoplex 5 in 7 of the 8 children $(0.13 \pm 0.02$ $\mathrm{mmol} / \mathrm{l}$. to $0.07 \pm 0.02 \mathrm{mmol} / \mathrm{l}$. $(P<0.01)$ and $0 \cdot 14 \pm 0.03$ to $0 \cdot 10 \pm 0.03 \mathrm{mmol} / \mathrm{l}$. in the low and high infusion groups, respectively) (Table III).

Plasma insulin and growth hormone concentrations. Only one of the children (Case 6) showed a marked change in growth hormone concentration during Aminoplex 5 infusion. The initial value was $42 \mathrm{ng} / \mathrm{ml}$ rising to $82 \mathrm{ng} / \mathrm{ml}$ after the infusion of amino acids (Table III). Plasma insulin values were obtained from 4 subjects. Consistent 
TABLE

Metabolic effects of.

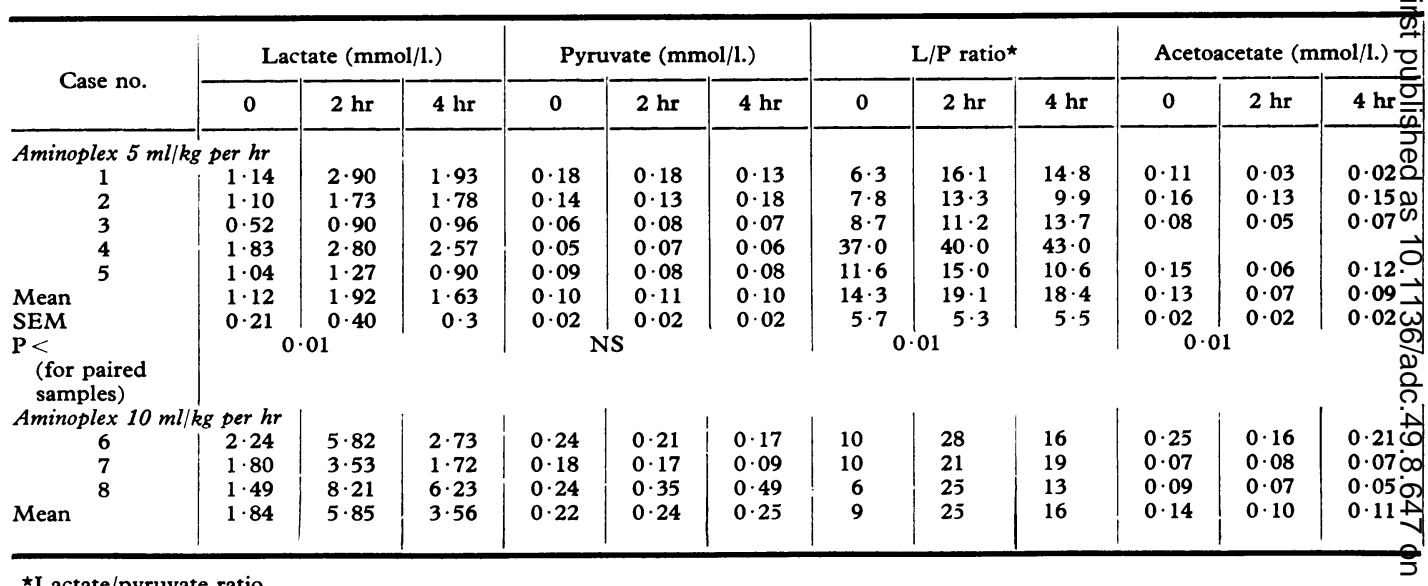

increments in plasma insulin concentrations did not occur (Table III).

\section{Discussion}

The aim of intravenous feeding in children is to prevent protein breakdown, to maintain blood and tissue constituents within normal limits, and to provide adequate calories for normal metabolism and growth.

Previous reports of long-term intravenous feeding in children have emphasized the problem of metabolic acidosis (Harries, 1971; Heird et al., 1972). The mechanism of this effect has not been clearly shown. Cornblath, Wybregt, and Baens (1963) showed that fructose infusion in neonates resulted in the formation of lactic acid, and Andersson, Brohult, and Sterner (1969) reported severe metabolic acidosis resulting in the death of one child, during fructose infusion. Fructose is a widely used carbohydrate source in commercially available amino acid preparations and Harries (1972) emphasized the danger of metabolic acidosis developing during infusion of such solutions in children. This aspect has recently been reemphasized by Woods and Alberti (1972) in their study with adult patients, and they pointed out that the risk of developing lactic acidosis is enhanced by the simultaneous administration of ethanol, a view supported by others (Peaston, 1973; Rickett and Bowen, 1973). All our patients developed hyperlactataemia after an infusion of Aminoplex 5, which contains sorbitol and ethanol.

Sorbitol is metabolized to fructose by the enzyme sorbitol dehydrogenase (Blakley, 1951; Seeberg,
McQuarrie, and Secor, 1955; Adcock and Gray, 1957; Murisasco et al., 1966) (Fig. 4), and an increase in blood fructose concentration during sorbitol infusion has been reported in man (Schultis and Beisbarth, 1972). It could be predicted, therefore, that demonstrable concentrations of fructose should be present in the blood during Aminoplex 5 infusion if similar pathways exist in children. This could in turn lead to enhanced lactate production, particularly in the presence of ethanol.

Our results show that with the exception of one infant, all the children had fructose in the blood during and after Aminoplex 5 infusion. The patient in which this did not occur was the preterm infant (Case 1). This suggests that sorbitol is metabolized to fructose in children but that this pathway may not be present in preterm infants.

A rise in blood lactate concentration occurred in all patients at the end of the Aminoplex 5 infusion. The increase was dose related, one patient in the high dose group achieving a blood lactate concentration of $8.2 \mathrm{mmol} / \mathrm{l}$. Blood $p \mathrm{H}$ was not measured in all the patients since it was thought not to be ethically justifiable to perform repeated arterial punctures. However, blood gas analysis was carried out during the study on the preterm infant, Case 1, who had an indwelling radial artery catheter. Arterial $p \mathrm{H}$ was $7 \cdot 44$ before Aminoplex 5 infusion, $7 \cdot 39$ at the end of the infusion, and $7 \cdot 40$ two hours later. No changes in $\mathrm{PaO}_{2}$ or $\mathrm{PaCO}_{2}$ occurred. These observations indicate that this infant was able to compensate satisfactorily for the rise in organic acid concentration. It is not known whether a fall 
III

Aminoplex 5 infusion

\begin{tabular}{|c|c|c|c|c|c|c|c|c|c|c|c|}
\hline \multicolumn{3}{|c|}{ Glucose (mmol/1.) } & \multicolumn{3}{|c|}{ Fructose (mmol/1.) } & \multicolumn{3}{|c|}{ Insulin $(\mu \mathbf{U} / \mathbf{m l})$} & \multicolumn{3}{|c|}{ Growth hormone (ng/ml) } \\
\hline 0 & $2 \mathrm{hr}$ & $4 \mathrm{hr}$ & 0 & $2 \mathrm{hr}$ & $4 \mathrm{hr}$ & 0 & $2 \mathrm{hr}$ & $4 \mathrm{hr}$ & 0 & $2 \mathrm{hr}$ & $4 \mathrm{hr}$ \\
\hline $\begin{array}{l}1 \cdot 52 \\
4 \cdot 40 \\
4 \cdot 62 \\
9 \cdot 24 \\
3 \cdot 63 \\
4 \cdot 68 \\
1 \cdot 26\end{array}$ & $\begin{array}{l}2 \cdot 71 \\
5 \cdot 25 \\
5 \cdot 26 \\
4 \cdot 44 \\
3 \cdot 46 \\
4 \cdot 22 \\
0 \cdot 50 \\
N S\end{array}$ & $\begin{array}{c}1 \cdot 71 \\
5 \cdot 38 \\
3 \cdot 81 \\
4 \cdot 07 \\
3 \cdot 22 \\
3 \cdot 64 \\
0 \cdot 59 \\
\text { NS }\end{array}$ & $\begin{array}{l}0 \\
0 \\
0 \\
0 \\
0 \\
0 \\
0\end{array}$ & $\begin{array}{l}0 \\
0.25 \\
0.59 \\
0.55 \\
0 \\
0.28 \\
0.12\end{array}$ & $\begin{array}{l}0 \\
0 \cdot 24 \\
0 \cdot 35 \\
0 \cdot 20 \\
0 \cdot 10 \\
0 \cdot 18 \\
0 \cdot 06\end{array}$ & $\begin{array}{r}3 \\
8 \\
10 \\
\\
7\end{array}$ & $\begin{array}{r}8 \\
10 \\
16 \\
9 \\
11\end{array}$ & $\begin{array}{l}9 \\
4 \\
7\end{array}$ & $\begin{array}{r}25 \\
4 \\
3 \\
9 \\
\\
10 \\
5\end{array}$ & $\begin{array}{r}16 \\
6 \\
2 \\
9 \\
\\
8 \\
3\end{array}$ & $\begin{array}{r}10 \\
5 \\
2 \\
5 \\
\\
6 \\
2\end{array}$ \\
\hline $\begin{array}{l}4 \cdot 76 \\
4 \cdot 30 \\
4 \cdot 40 \\
4 \cdot 49\end{array}$ & $\begin{array}{l}9 \cdot 44 \\
5 \cdot 57 \\
5 \cdot 07 \\
6 \cdot 69\end{array}$ & $\begin{array}{r}10 \cdot 38 \\
3 \cdot 20 \\
5 \cdot 32 \\
6 \cdot 27\end{array}$ & $\begin{array}{l}0 \\
0 \\
0 \\
0\end{array}$ & $\begin{array}{l}1 \cdot 54 \\
0 \cdot 26 \\
0 \cdot 60 \\
0 \cdot 80\end{array}$ & $\begin{array}{l}1 \cdot 40 \\
0 \cdot 46 \\
0 \\
0 \cdot 62\end{array}$ & 11 & 9 & 8 & $\begin{array}{r}41 \\
3\end{array}$ & $\begin{array}{r}82 \\
4\end{array}$ & $\begin{array}{r}44 \\
2\end{array}$ \\
\hline
\end{tabular}

in $p \mathrm{H}$ occurred in the other patients, though none of the children showed clinical evidence of acidosis, as evidenced by a change in respiratory pattern. It is possible that a rise in lactic acid concentration could cause signs of acidaemia in those patients whose compensatory mechanism is already impaired, as a result of hepatic disease or anoxia. It is particularly important to give such patients the 24-hour requirement of amino acids in small aliquots interspersed with Intralipid, saline, or dextrose, throughout the day rather than as a continuous infusion over a few hours.

Blood pyruvate concentrations were unchanged in all subjects but the $\mathrm{L} / \mathrm{P}$ ratio increased. This ratio reflects the cytoplasmic $\mathrm{NAD}^{+}: \mathrm{NADH}_{2}$ (pyridine nucleotide) ratio (Hohorst, Kreutz, and Bücher, 1959), and a rise in the ratio is commonly associated with tissue anaerobiosis (Woods, 1971). A fall in $p \mathrm{H}$ will also cause a rise in $\mathrm{L} / \mathrm{P}$ ratio without implying intracellular hypoxia. However, the rise in ratios found in our patients are much greater than would be expected from a moderate fall in extracellular fluid $p \mathrm{H}$ alone (Alberti et al., 1972a).

The relative concentrations of lactate and pyruvate are related to the proportions of reduced and oxidized pyridine nucleotide in cell cytoplasm,
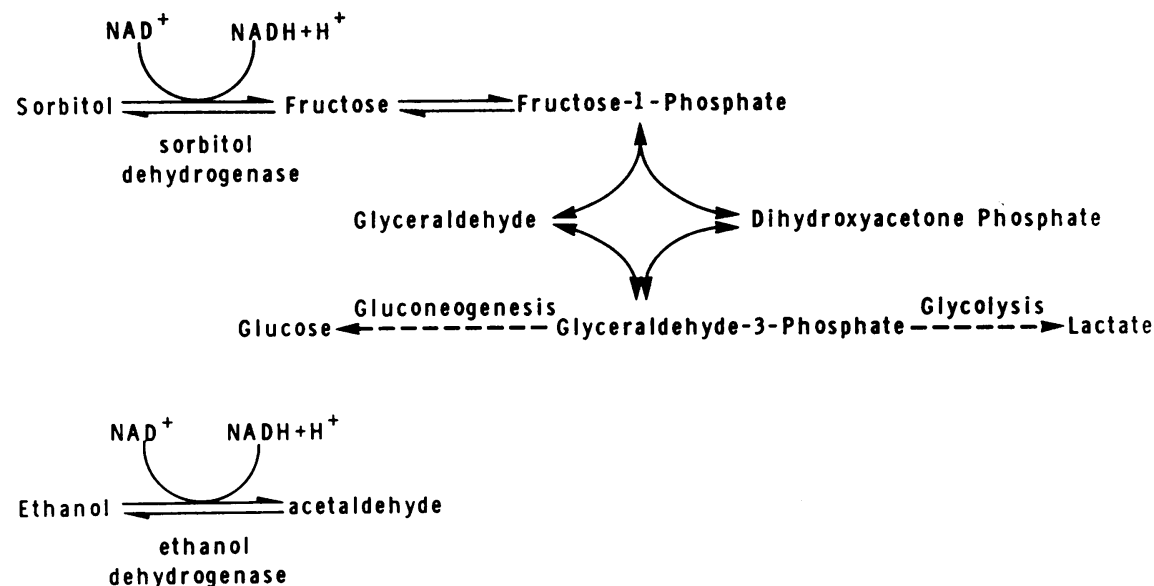

FIG. 4.-The pathways for the metabolism of sorbitol and ethanol. 
since lactate $+\mathrm{NAD}^{+} \rightleftharpoons$ pyruvate + NADH. Utilization of $\mathrm{NAD}^{+}$will shift the equilibrium of the reaction to the left and increase the proportional concentration of lactate. Sorbitol is metabolized to fructose by sorbitol dehydrogenase, a reaction utilizing $\mathrm{NAD}^{+}$, and ethanol is also metabolized by a dehydrogenase reaction to acetaldehyde (Fig. 4). Thus, the concurrent metabolism of ethanol with sorbitol during Aminoplex 5 infusion would cause a rise in $\mathrm{L} / \mathrm{P}$ ratio and lactate concentration through utilization of $\mathrm{NAD}^{+}$.

A second contributory factor could be the rapid conversion of fructose to lactate. In the perfused rat liver $30 \%$ of a fructose load is converted to lactate (Woods, Eggleston, and Krebs, 1970; Woods, 1970). Thus the metabolic effects in our patients occurred exactly as would be predicted from the known metabolism of sorbitol and ethanol.

The effects of amino acid preparations for intravenous feeding on plasma insulin and growth hormone concentrations in children have not been widely studied, though amino acids, particularly arginine, are both growth hormone and insulin secretagogues. We found no consistent increase in plasma insulin with the doses used though a transient rise might have been missed. Arginine is a potent insulin secretagogue with responses occurring at infusion rates of as little as $0.054 \mathrm{~g} / \mathrm{kg}$ per $\mathrm{hr}$. A mixture of essential amino acids is as potent weight for weight (Fajans et al., 1972). The maximum infusion rate used here was $0.04 \mathrm{~g}$ arginine/kg per $\mathrm{hr}$, below the threshold value; however, total essential amino acids were given at $0.19 \mathrm{~g} / \mathrm{kg}$ per $\mathrm{hr}$, which should have caused a response. It is possible that a better insulin response and thus a greater anabolic effect, would be achieved by adding glucose rather than sorbitol and ethanol to the infusate in view of the synergistic effect of essential amino acids and glucose on insulin secretion (Floyd et al., 1970).

Growth hormone concentrations increased during Aminoplex infusion in only one infant. The failure to stimulate insulin and growth hormone secretion could be manifestations of the stressed states of children. Thus catecholamine release is known to inhibit insulin secretion (Porte, 1967), while Alberti and Hockaday (1973) have shown that the most seriously ill adults with diabetic ketoacidosis have the lowest growth hormone response to a fall in blood glucose.

In order to provide calories for total intravenous feeding with Aminoplex 5, an infusion rate between $5 \mathrm{ml}$ and $10 \mathrm{ml} / \mathrm{kg}$ per hr is required. This implies that metabolic changes similar to those reported here are likely to occur during long-term use, particularly with doses close to $10 \mathrm{ml} / \mathrm{kg}$ per hr. We have no evidence, despite the metabolic abnormalities reported, that the condition of any of the children was adversely affected by Aminoplex 5 administration. 2 of the children in the series subsequently died (Cases 6 and 8) several days after ending the intravenous feeding regimens. One child (Case 2) had rapidly progressing ulcerative colitis. He was maintained for 12 weeks on total intravenous nutrition using Aminoplex 5 and Intralipid. ${ }^{\star}$ On this regimen he remained well, gained weight, and subsequently has developed normally.

The main conclusion from this study is that the use of a combination of amino acids with sorbitol and ethanol for intravenous feeding may cause hyperlactataemia. While such preparations can be life-saving, their dangers would be obviated by the use of preparations containing only amino acids, such as Aminoplex 14, together with additional glucose. This is of particular importance when using intravenous feeding regimens in preterm infants who may be unable to metabolize sorbitol.

We thank Professor J. P. M. Tizard, Drs. H. Ellis and D. Pickering, Mr. R. Guy, and Mr. J. Kenwright for permission to study their patients; Dr. R. Brown and the nursing staff of the paediatric wards for their assistance; the Department of Medical Illustration for preparing the figures; and Mrs. H. Dhar, Mrs. S. Slade, and Mr. G. Johnson for technical assistance. Dr. R. Turner kindly performed the insulin assays. The authors acknowledge financial support from the Wellcome Trust and the British Diabetic Association.

\section{REFERENCES}

Adcock, L. H., and Gray, C. H. (1957). The metabolism of sorbitol in the human subject. Biochemical fournal, 65, 554.

Alberti, K. G. M. M., Darley, J. H., Emerson, P. M., and Hockaday, T. D. R. (1972a). 2, 3-diphosphoglycerate and tissue oxygenation in uncontrolled diabetes mellitus. Lancet, 2, 391.

Alberti, K. G., and Hockaday, T. D. (1973). Diabetic coma: serum growth hormone before and during treatment. Diabetologia, $\mathbf{9}$, grow.

Alberti K. G. M. M.,, Record, C. O., Williamson, D. H., and Wright, R. (1972b). Metabolic changes in active chronic hepatitis. Clinical Science, 42, 591.

Andersson, G., Brohult, J., and Sterner, G. (1969). Increasing metabolic acidosis following fructose infusion in two children. Acta Paediatrica Scandinavica, 58, 301.

Blakley, R. L. (1951). The metabolism and anti-ketogenic effects of sorbitol. Sorbitol dehydrogenase. Biochemical fournal, 49, 257.

Cornblath, M., Wybregt, S. H., and Baens, G. S. (1963). Studies of carbohydrate metabolism in the newborn infant. VII. Tests of carbohydrate tolerance in premature infants. Pediatrics, 32, 1007.

Fajans, S. S., Floyd, J. C., Jr., Knopf, R. F., Pek, S., Weissman, P., and Conn, J. W. (1972). Amino acids and insulin release in vivo. In Impact of Insulin on Metabolic Pathways, p. $59 . \quad$ Ed. by E. Shafrir. Academic Press, New York.

Floyd, J. C., Jr., Fajans, S. S., Pek, S., Thiffault, C., Knopf, R. F., and Conn, J. W. (1970). Synergistic effect of essential amino acids and glucose upon insulin secretion in man. Diabetes, 19, 109.

^Paines and Byrne Ltd., Greenford, Middx. 
Harries, J. T. (1971). Intravenous feeding in infants. Archives of Disease in Childhood, 46, 855.

Harries, J. T. (1972). Metabolic acidosis during intravenous feeding of infants. In Parenteral Nutrition, p. 266. Ed. by A. W. Wilkinson. Churchill Livingstone, London.

Heird, W. C., Driscoll, J. M., Schullinger, J. N., Grebin, B., and Winters, R. W. (1972). Intravenous alimentation in pediatric patients. Fournal of Pediatrics, 80, 351.

Hohorst, H. J., Kreutz, F. H., and Bücher, Th. (1959). Über Metabolitgehalte und Metabolit-Konzentrationen in der Leber der Ratte. Biochemische Zeitscheift, 332, 18.

Murisasco, A., Unal, D., Jauffret, P., and de Belsunce, M. (1966). The clinical use of sorbitol $30 \%$ solution for intravenous infusion. Aggressologie, 7, 253.

Peaston, M. J. T. (1973). Dangers of intravenous fructose. Lancet, $1,266$.

Porte, D. (1967). A receptor mechanism for the inhibition of insulin release by epinephrine in man. Fournal of Clinical Investigation, 46, 86.

Rickett, J. W. S., and Bowen, D. J. (1973). Danger of intravenous fructose. Lancet, 1, 489.
Schultis, K., and Beisbarth, H. (1972). Posttraumatic energy metabolism. In Parenteral Nutrition, p. 255 . Ed. by A. W. Wilkinson. Churchill Livingstone, London.

Seeberg, V. P., McQuarrie, E. B., and Secor, C. C. (1955). Metabolism of intravenously-infused sorbitol. Proceedings of the Society for Experimental Biology and Medicine, 89, 303.

Slein, M. W. (1963). Methods of Enzymatic Analysis, p. 117. Ed. by H. U. Bergmeyer. Verlag Chemie, Weinheim.

Woods, H. F. (1970). Carbohydrate metabolism of the liver. D. Phil. Thesis. University of Oxford.

Woods, H. F. (1971). Some aspects of lactic acidosis. British fournal of Hospital Medicine, 6, 668.

Woods, H. F., and Alberti, K. G. M. M. (1972). Dangers of intravenous fructose. Lancet, $2,1354$.

Woods, H. F., Eggleston, L. V., and Krebs, H. A. (1970). The cause of hepatic accumulation of fructose, 1-phosphate on fructose loading. Biochemical fournal, 119, 501.

Correspondence to Dr. A. Aynsley-Green, Department of Paediatrics, John Radcliffe Hospital, Headington, Oxford OX3 9DU.

The following articles will appear in future issues of this journal:

Biochemical state of the vitreous humour of infants at necropsy. P. G. F. Swift, E. Worthy, and J. L. Emery. Hypernatraemia and uraemia in unexpected death in infancy. J. L. Emery, P. G. F. Swift, and E. Worthy. Quality of survival after artificial ventilation of the newborn. R. Dinwiddie, D. H. Mellor, S. H. C. Donaldson, M. E. Tunstall, and G. Russell.

Clinical and biochemical studies on treatment of the Lesch-Nyhan syndrome. R. W. E. Watts, R. O. McKeran, E. Brown, T. M. Andrews, and M. I. Griffiths.

Iliac arteries in children with a single umbilical artery: structure, calcifications, and early atherosclerotic lesions. W. W. Meyer and J. Lind.

Role of house-dust mites in childhood asthma. J. K. Sarsfield.

Mite-sensitive asthma of childhood: trial of avoidance measures. J. K. Sarsfield, G. Gowland, R. Toy, and A. L. E. Norman.

Assessment of gestational age in twins. M. P. Keet, A. M. Jaroszewicz, and A. le R. Liebenberg. Acute intracranial hypertension after nalidixic acid administration. T. Deonna and J. P. Guignard. 